\title{
Effects of Place-Based and Activity-Based Approaches in Technical Education, Interest and Retention
}

\author{
Alhassan Ndagi Usman 1,", Aede Hatib Musta'ámal', Hassan Abdullahi Muhammad², \\ Idris Abubakar Mohammed ${ }^{2}$ \\ ${ }^{1}$ Department of Technical and Engineering Education, Faculty of Social Sciences and Humanities, Universiti Teknologi Malaysia \\ (UTM), Malaysia \\ ${ }^{2}$ Department of Industrial and Technology Education, Federal University of Technology, USA
}

Received January 22, 2020; Revised April 1, 2020; Accepted April 21, 2020

Copyright $\bigcirc 2020$ by authors, all rights reserved. Authors agree that this article remains permanently open access under the terms of the Creative Commons Attribution License 4.0 International License

\begin{abstract}
This study was designed to determine the effects of place-based and activity-based learning approaches on students' achievement, interest and retention in technical education. A pre-test, post-test, non-equivalent control group, quasi-experimental research design was adopted. The study constituted a total number of 122 subjects, 63 for the place-based education, while 59 for the activity-based learning. Three research questions and three null hypotheses, tested at 0.05 level of significance, guided the study. The instruments used for data collection were Technical Education Cognitive Achievement Test (TECAT), Technical Education Psychomotor Achievement Test (TEPAT) and Technical Education Interest Inventory (TEII) The reliability coefficient obtained was 0.78. Mean was used to answer the research questions; while ANCOVA was employed to test the hypotheses. The study revealed that students taught Technical education using the place-based education instructional approach had a higher mean score than students taught using the activity-based learning teaching method in cognitive achievement test, psychomotor achievement test and test for retention of learning. It was recommended among others that; The National Board for Technical Education (NBTE) should consider a review of technical education curriculum for Technical Colleges with a view to incorporating the place-based education instructional approach into the teaching of technical education.
\end{abstract}

Keywords Place-Based, Activity-Based Learning, Technical Education, Interest, Achievement

\section{Introduction}

Technical education is vital for nation growth and industrialization. Thus, the skills, abilities and competencies the nation needs are rooted in technical and vocational education, which is essential towards the social and economic empowerment of a nation. Consequently, every nation that believes in education as a par excellence instrument for national development must recognize the importance of vocational and technical education and give it the desired attention and support it deserves. It is in this wisdom that the National Education Policy (2014) places significant emphasis on improving vocational and technical education for the nation's overall development. The much talked about vocational and technical growth, however, may not materialize unless the youth acquire the knowledge, interest, aptitude and interpersonal skills needed to build and produce basic necessities of life.

Doolittle (2010) states that one of the goals of vocational and technical education is to make school leavers more employable. Regrettably, however, because of public aversion to vocational and technical education (VTE), the aim seems to have not been achieved, which explains the prevalence of poverty, unemployment, prostitution, drug abuse, hunger, terror, rebellion, armed robbery and other forms of social vices in Nigeria today.

This continued low academic performance most frequently undermines the interest of students and can central to poor holding of skills in technical education as with others negative belongings of technical education aims of the whole programme. Students also hate a course that shows a high rate of analysis failure and retaining of information strongly depends on achievement and desire. Because of such a weak technical education students' success one is supposed to be concerned. Nonetheless, by implementing education / knowledge methods grounded in a problem-based method to knowledge, teaching and learning in technical education could be improved

Problem-based education (PBL) is also single of the 
constructivists knowledge methods that introduces critical contextualized real-world situations, offering learning tools, feedback and instruction as students gain knowledge of material and problem-solving skills. PBL is an interactive, centered on the student, identity-directed and background learning style. Problem-based learning allows students to deliberately discover additional than the teacher's information tools, includes main materials, online resources and people in the communal, and attraction on expertise after different topic parts. Ogbuanya (2008) Therefore, it proposed that undergraduates will assume responsibility for their own learning, and must be those of educators seen additional as counsellors and less as information presenters. Consequently, PBL-rooted Informative approaches can be a certain way of teaching philosophy as well as realistic technical education. This lets the students learn how to read, and eliminates the teaching of the teacher as the learners are actively involved.

Place-based education and activity-based approaches are common amongst teaching and learning methods engrained in problem-based learning. Place-based education, also called place-based pedagogy, place-based learning, experiential education, community-based education, sustainable education, environmental education or, more rarely, service learning, is a philosophy of education. Place-based curriculum is used for various purposes in several training fields. Place-based education applies, according to Woodhouse and Knapp (2010), to community-focused learning, ecological education and bioregional training. While place-based education is rooted in environmental education, this approach can be differentiated from traditional environmental education, since the founders of place-based education concentrated on both social and natural environments (Smith, 2007).

Although the idea of place is rooted in the geography discipline, spot-based projects are generally multidisciplinary and interdisciplinary (Resor, 2010). Place-based education, used in language, humanities, mathematics, social studies, and science education, strengthens the understanding of students regarding local history, community, environment, environments, resources, and interactions with them. It allows teachers and students to make use of the schoolyard, community, public spaces and other unique spaces as tools to transform neighborhoods into classrooms (PEEC, 2010). Furthermore, this instructional approach successfully helps children resolve the disconnection between their lives and school because of their ability to harmonize different location features (Smith, 2012). In short, location-based education helps students learn to care about the world by helping them understand the place in which they live and behave on their own backyards and communities (PEEC 2010). Place-based teaching / learning approach such as Event-Based teaching / learning is aimed at improving the achievement of students in the classrooms of the $21 \mathrm{st}$ century. In technical education, however, this is yet to be confirmed.

The concept of Activity-Based learning reflects the constructivist philosophy of education and is pedagogy focused on children. Activity-Based learning can be characterized as the means of teaching, wherever events of changed types, appropriate and appropriate to exact topics were seamlessly combined hooked on the standard teaching resources and approaches for involving undergraduates in teaching-learning or teaching activities and involve them productively (Suydam and Higgins, 2012). An Activity - Based approach to learning requires that students become active participants rather than passive learners. An Activity-Based learning methodology includes three elements, according to Haury and Rilero (2014): : I hands-on; students are actually allowed to carry out physical tasks while they create meaning and gain understanding; (ii) minds-on; exercises concentrate on the core concepts, allowing students to establish processes of thought and encouraging them to challenge and seek answers that improve their awareness and thus acquire a real world understanding; ; and (iii) authentic; problem-solving students are presented, which integrates real-life questions and issues in a way that promotes collaborative effort, discussion with teachers or experts, and generalization to wider ideas and implementation. Throughout Activity-based teaching, students not only communicate with resources or make observations, but also engage throughout creating processes of learning and constructing meaning to gain understanding. It is believed that direct encounters with natural phenomena can offer attention and thinking (Lumpe \& Oliver, 2011). However, it is not yet known which of those teaching methods will be best aimed at enhancing the achievement of the students in technical education.

Academic achievement has been defined as viewing how well a person has performed their cognitive tasks (Avoseh, 2015). The author is also of the opinion that academic achievement can also be the general skill of students in relation to a defined level called Pass Marks for their offered subjects. This pass mark is relative to him and can be described arbitrarily as $40 \%$ or $50 \%$. Sometimes, this can be called the criterion of quality (Aremu \& Adika, 2010). The word also means the attainment of a student's achievement with his peers in his school work. Achievement in technical education means success in the subject of school as score symbolized or marked on the test in accomplishment of technical education. Anene (2009) noted that the cognitive or psychomotor performance of the students is quantified in comparison to that of other students of his age by a calculation of the academic standing of the students.

Retention of learning is a repeat performance of the activity learned earlier, elicited after a time interval by a learner (Damire, 2014). Among other things, it is influenced by the degree of initial learning, the learning process and the memory capacity of the learner (Demmert, 
2011). Retaining merely mentions to how much a individual recalls without practice later an interlude real time, and it's the change amongst what is first remembered and what is later overlooked. Learning retaining can also respond to report that persists outside the early test and is validated for two weeks, or even more of testing later the material is imparted and checked. Haynie (2010) clarified that learning retaining is assessed using double trials: the early test besides the retarded retaining test. The initial test is the test used at or directly after the instruction while the delayed retention tests are those given two or more weeks after instruction and initial test to assess engaged information. Retaining is the mind's preservative element (Kundu \& Totoo, 2017). Something enters consciousness leaves trace or impression, and in the form of images is stored in the brain. Boyle, Duffy and Dunleavy (2013) concluded that the success of students in learning is influenced by issues such as the skill of educators, incentive, meaning of topic matter, instructional strategies, learner's memory capacity and learner's interest in learning.

Interest is an important factor in learning, it is seen as an individual's feeling when he or she wants to know or learn more about something like Technical Education. Obodo (2011) concluded that attention is the magnetism that induces or requires a child to reply to a given stimulus. In other words, if a particular stimulation (e.g. teaching method or subject matter) is appealing and arousing or relaxing, a child develops interest. This means that if the child is interested in that particular lesson, he will have to wage consideration as a lesson energy on. Harbour-Peters (2012) maintained that motivation comes as a result of curiosity or eagerness not to know by coercion. Interest is an important learning attribute, because if a student has a strong interest in a particular subject, he or she not only enjoys studying the subject, but would also gain pleasure from the subject's knowledge. Value is interpreted in relation to internal state of mind or external environment reactions or experiential predisposition. Interest can also be seen as the readiness to respond to or against a particular situation, person or things, e.g. with love or hate fear or anger to a certain degree or severity. That is to say, interest is that inner state which influences the personal actions of the individual. This description suggests that the participation of students in technical education implies the student's emotions, experiences and feelings in technical education and related tasks.

\section{Statement of the Problem}

The services required in technical education training to students are becoming increasingly complex. This is due to the rapid technological growth rate in the industry. Technical education

has terms of technology changed particularly in the 21st century as proprietors in the creation of technical education are they searching for qualities like critical thinking skills, innovation and problem-solving services for workers with workplace competencies.

The traditional teaching approaches adopted by greatest technical education educators in higher institutions (such as lecture and presentation methods) seem insufficient to equip the technical education with job services such as versatility, adaptableness, innovation, high-order thought and problem solving. Such teaching / learning approaches are educator-centered; therefore, they don't offer alumni ample chances to purposeful and engage for everyone vigorously in the learning procedure. The brief advent of these teaching approaches might be partially answerable for the deprived presentation of technical education undergraduates in inspections in the Niger State over the years. It has been observed that most technical education craftsmen from technical schools frequently leave their profession even after employment or have their focus split over a particular vocation and even take up jobs such as petroleum vending, unlawful external conversation marketplace sector and party-political tuggers that do not fit into that preparation they undergo have established. Accordingly, instructional methods needed to be more successful in refining not only undergraduates' theoretical and psychomotor accomplishment but also students' interest in technical education technology. Therefore this analysis is conceived for the ambition of impacts of Place-based and Activity - Based learning methods on higher institution students' accomplishment, gender, interest besides retaining in Technical education skill in Niger State.

\section{Purpose of the Study}

1. Place effect- Functional and activity-based approaches to learning on the academic performance of the students in technical education.

2. Place impact - Focused and experience-based learning strategies on sustaining learning in Technical Education for students.

3. Place - Learning approaches focused on activity and centered on the students ' interest in pursuing Technical Education.

\section{Research Question}

1. What is the impact of Place-based and Activity-based approach to learning on the cognitive accomplishment of students in technical education?

2. What is the impact of Place-based and Activity-Based Learning Approach on maintaining learning in technical education for students?

3. What is the impact of Place-based and Activity-based method to learning on the interest of students in pursuing technical education? 


\section{Hypothesis}

HO1: The mean impact of Place-Based and EventBased learning approach on the academic accomplishment of students in technical education does not differ significantly.

HO2: There is no significant difference between the mean impact of gender on students ' academic achievement in technical education (male and female) once imparted by means of the place-based and Activity-based method to learning.

HO3: The mean interaction impact of treatment given to students taught using Place-Based and Activity-Based learning method and gender (male and female) by admiration to their mean scores in the cognitive accomplishment trial for technical education is not important.

\section{Methodology}

This research relies on a quasi-experimental approach. The proctored exam, the most posthaste architecture remained working specifically for the study. The study remained carried out at Federal University of Technology, Minna, Niger State, Nigeria because the school is one of the schools in Niger State which offered technical education. The populace for this study is comprised of the 122 participants in second year from Federal University of Technology in Department of Industrial and Technology Education, Minna, Nigeria. The sample was chosen using simple random sampling. Second year students were used because in their first year they studied Technical Education and a basic understanding of the vocabulary, materials, and tools of trade would have been given. Populace circulation was done rendering to colleges. Respectively complete class contains male and female undergraduates who were used for the analysis for the entire population of 122 .

The methods used to collect data for this analysis consist of a cognitive performance test in technical education (TECAT). TECAT held both content and face validation. To ensure the validity of their material, a specification table was built for the TECAT. A overall of 82 numerous high-quality objects were pinched for the TECAT based on the specification table. Expert from ITE Department, FUT, Minna and two Technical Education educators on or after tech. institution in Niger State. The TECAT remained verified on 40 second year scholars at Niger State College of Education Minna, Nigeria's Technical and Vocational Education Students using reliability test retest technique. TECAT's reliability has been calculated using the Pearson Product Moment Correlation Coefficient and has been Recently discovered to be.78.

Aimed at the educators who remained used as investigation helpers, a three-day comprehensive training was planned. Prior to the therapy exercise, pre-test was given to the two sets by means of TECAT to assess the equality of the topics allocated to the Place-based learning set and Activity-Based learning set. Formerly, care in all the sets began. Place-based learning group was taught technical education with PBE Learning Plans thus technical education was imparted in the Activity-Based learning community using the ABL teaching tactics. Which Eight weeks.

The statistics composed from the pre-test, post-test, remained examined by means of mean to answer the study questions while Covariance Analysis (ANCOVA) remained used to trial the significance level of null hypotheses at 0.05 .

\section{Results}

What is the impact of Place-based and Activity-based approach to learning on the cognitive accomplishment of students in technical education?

The mean of pre-test scores and post-test scores of the two groups are presented in table 1 below.

Table 1. Mean and Standard Deviation of Pretest and Posttest Results in the Academic Performance Test of disabled learning group and exercise-based learning group

\begin{tabular}{|c|c|c|c|c|c|c|}
\hline Group & $\mathbf{N}$ & $\begin{array}{c}\text { Pretest } \\
\text { scores } \\
\bar{\chi}\end{array}$ & SD & $\begin{array}{c}\text { Post test } \\
\text { score } \\
\bar{\chi}\end{array}$ & SD & $\begin{array}{c}\text { Mean } \\
\text { Gain } \\
\bar{\chi}\end{array}$ \\
\hline PBE & 63 & 31.66 & 9.63 & 66.69 & 9.84 & 35.03 \\
\hline ABL & 59 & 28.98 & 10.08 & 62.54 & 10.19 & 33.56 \\
\hline
\end{tabular}

The data obtainable in Table 1 indicates that the PBE method set had a Mean score of 31.66 and a SD of 9.63 in the pre-test and a Mean score of 66.69 and a SD of 9.84 in the post-test resulting in a pre-test gain of 35.03 after-test. Activity-based learning method required a mean score of 28.98 and a SD of 10.08 in the pre-test and a mean after test of 62.54 and a standard deviation of 10.19 , by a mean pre-test gain of 33.56 in the post-test. By these findings, together the learning based on problems and the learning based on events successful in refining the cognitive accomplishment of students in technical education, nevertheless the impact of PBE Method on refining the cognitive accomplishment of students in woodwork expertise is greater than that of ABL Method.

\subsection{Research Question Two}

What is the impact of Place-based and Activity-Based Learning Method on maintaining learning in technical education for students? 
Table 2. Mean and standard deviation of PB approach group and ABL approach group Post-test and retention results in cognitive thinking test retention.

\begin{tabular}{ccccccc}
\hline Group & $\mathbf{N}$ & $\begin{array}{c}\text { Post-test } \\
\overline{\boldsymbol{\chi}}\end{array}$ & SD & $\begin{array}{c}\text { Retaining } \\
\text { score } \\
\bar{\chi}\end{array}$ & SD & $\begin{array}{c}\text { loss } \\
\bar{\chi}\end{array}$ \\
\hline PBE & 63 & 66.69 & 9.84 & 54.08 & 8.43 & 12.61 \\
\hline ABL & 59 & 62.54 & 10.19 & 49.00 & 9.98 & 13.54 \\
\hline
\end{tabular}

Table 2 displays that the PBE method set required a mean score of 66.69 and a SD of 9.84 in the post-test and a mean score of 54.08 and a SD of 8.43 in learning retaining allowing a mean loss of 12.61 in the post-test, retaining trial. ABL method set had an average score of 62.54 and a SD of 10.19 in the post-test and a retention test mean of 49.00 and SD of 9.98 , with a post-test, mean loss of 13.54 with the result, PBE method set retaining of learning is higher than retaining of set learning in ABL. Consequently, the results indicate that the community teaching wood work expertise with a method to PB maintained their learning improved than those imparted with ABL.

\subsection{Research Question Three}

What is the impact of Place-based and Activity-based method to learning on the interest of undergraduates in pursuing technical education?

The mean of pre-test scores and post-test scores of the two groups are presented in table 4 below.

Table 3. Mean and Standard Deviation of Pre-test and Post-test Interest Scores of undergraduates imparted using PBE and ABL methods.

\begin{tabular}{ccccccc}
\hline Group & $\mathbf{N}$ & $\begin{array}{c}\text { Pretest } \\
\text { scores } \\
\overline{\mathbf{\chi}}\end{array}$ & SD & $\begin{array}{c}\text { Posttest } \\
\text { scores } \\
\bar{\chi}\end{array}$ & SD & $\begin{array}{c}\text { Mean } \\
\text { gain } \\
\bar{\chi}\end{array}$ \\
\hline PBE & 63 & 60.30 & 10.38 & 86.36 & 8.78 & 26.06 \\
\hline ABL & 59 & 68.64 & 9.20 & 86.49 & 7.53 & 19.85 \\
\hline
\end{tabular}

The data presented in Table 3 indicates that the PBE approach category required a Mean interest score of 60.30 and a Standard Deviation of 10.38 in the pre-test and a Mean score of 86.36 and a Standard Deviation of 8.78 in the post-test resulting in a pre-test gain of 26.06 after test. ABL method had an interest Mean score of 68.64 and a standard deviation of 9.20 in the pre-test and a post-test Mean score of 86.49 and a standard deviation of 7.53, by a pre-test Mean gain of 19.85 after test. With these findings, the PBE approach and ABL method remain successful in stimulating the student interest in Technical Education but the effect of PB Approach on stimulating the awareness of students in technical education is greater than the $\mathrm{ABL}$ impact method.

\section{Hypotheses}

HO1: The mean impact of Place-Based and Event-
Based learning approach on the academic accomplishment of students in technical education does not differ significantly.

$\mathrm{HO}$ 2: There is no significant difference between the mean impact of gender on students ' academic achievement in technical education (male and female) once imparted by means of the place-based and Activity-based method to learning.

HO3: The mean interaction impact of treatment given to students taught using Place-Based and Activity-Based learning method and gender (male and female) by admiration to their mean scores in the cognitive accomplishment trial for technical education is not important.

Summary of Analysis of Covariance (ANCOVA) test for hypotheses $1,2 \& 3$ remain obtainable in table 4 below.

Table 4. Summary of Analysis of Covariance (ANCOVA) for Test of Significance of Effect of Treatments (PB and ABL), their Gender and Interaction Effect with Respect to their Mean Scores on Technical education Cognitive Achievement Test

\begin{tabular}{cccccc}
\hline Source & $\begin{array}{c}\text { Type III Sum } \\
\text { of Squares }\end{array}$ & df & $\begin{array}{c}\text { Mean } \\
\text { Square }\end{array}$ & F & Sig. \\
\hline $\begin{array}{c}\text { Corrected } \\
\text { Model }\end{array}$ & $6019.303^{\mathrm{a}}$ & 14 & 429.950 & 9.284 & .000 \\
\hline Intercept & 116029.049 & 1 & 116029.049 & 2505.394 & .000 \\
\hline METHOD & 3963.837 & 8 & 495.480 & 10.699 & .000 \\
\hline GENDER & 7.731 & 1 & 7.731 & .167 & .684 \\
\hline $\begin{array}{c}\text { GENDER } * \\
\text { METHOD }\end{array}$ & 82.602 & 5 & 16.520 & .357 & .877 \\
\hline Error & 4955.352 & 107 & 46.312 & & \\
\hline Total & 336096.000 & 122 & & & \\
\hline $\begin{array}{c}\text { Corrected } \\
\text { Total }\end{array}$ & 10974.656 & 121 & & & \\
\hline
\end{tabular}

a. R Squared $=.548$ (Adjusted R Squared $=.489$ )

$*$ Significant at sig of $\mathrm{F}<.05$

The statistics obtainable in Table 4 indicates F-calculated values for three effects: diagnosis, gender and care and gender communication outcome on the academic accomplishment of the students in technical education. The F-calculated treatment value is 10,699 , with an F-significance of a lesser amount of than 0.05 at.000. Therefore, the null-hypothesis that there is no important mean change amongst the influence of the PBE method and the ABL approach on the academic accomplishment of students in technical education is dismissed at the level of significance of 0.05 . The result suggests that the mean variance amongst the $\mathrm{PB}$ method effect besides the $\mathrm{ABL}$ method remained important. As shown in Table 9, the F-calculated value for gender is. 167 with a significance of $\mathrm{F}$ at.684 that is larger than.05. The null hypothesis that there is no significant difference from mean impact of gender (male and female) on the academic achievement of students in technical education is therefore agreed at the equal of significance of 0.05 . This indicates that in technical education there wasn't one substantial mean 
difference between the effects of gender on the academic achievement of the students. Treatment and gender interaction have a F-calculated value of. 357 with a value of $\mathrm{F}$ at. 877 greater than.05. Therefore, the null hypothesis that treatments and gender have no major interaction impact is acknowledged. This indicates that therapies given to students imparted with PB method and ABL learning method and their gender did not have a major association effect in terms of its mean scores on cognitive performance test for technical education.

\section{Discussion of the Results}

This research aimed to evaluate the effects of place-based and activity-based learning strategies on the accomplishment, participation besides retaining of technical college students in technical education, as well as their effect on gender. The discoveries which developed from the analysis are deliberated here.

The data obtainable in Table Submitted an answer to Question one of the studies. It has been exposed that PBE method and $\mathrm{PB}$ are successful in refining the cognitive accomplishment of students in technical education, but the impact of $\mathrm{PB}$ method in refining the perceptive accomplishment of students in technical education is greater than $\mathrm{ABL}$ method. Covariance scrutiny remained used to evaluate the first hypothesis (Table 4) at the measured F-value (10.699), Significance of F (.000) and level of confidence of.05. The outcome highlights the difference in mean in academic achievement in technical education amongst the impact of the Activity-based learning method and Place-based learning method was statistically significant. This means that in raising the academic performance of the students in technical education, PBE is more successful than ABL approach.

The above discoveries are constant with the discoveries of Kabiru (2010), Ade (2011) and Umar (2012) Who, in their distinct studies in other topics, originate that the guidance of PBE had a significant impact on the cognitive accomplishment of the students compared to other formats of instruction. The discoveries of this study too provision some works data, such as Araz (2010), who claimed that when learners are uncovered to original concepts introduced by various brainpowers, they will have a improved coincidental of learning, remembering the knowledge and adapting their learning knowledges to added circumstances that may lead to advanced accomplishment. Consequently, the outcome of this study regarding the cognitive achievement of the students is due to the care assumed to students in the PBE community. The discoveries might be described by the fact that the implementation by teachers of numerous instructional systems (such as active learning, collective learning, and self-assessment) in the PBE \& ABL laboratory interested to the changed intellects of the students and involved the undergraduates in the learning progression which enlarged their incentive to learn and improve their remembrance. The findings might also be described as follows: allowing students the chance to engage vigorously in the class by free contact take the educator and their nobles and enabling them to learn in sets and evaluate their success by including the undergraduates themselves in the learning process; thereby enhancing their capability to discover problems and express their personal thoughts. This in effect better-quality their learning and thoughtful capabilities that resulted in a profounder Intelligence of the ideas and ideologies of difficult technology related with technical education. It means that PBE approach undergraduates unstated and implemented more of their Technical Education learning than the added set of undergraduates that were imparted by ABL method.

The statistics obtainable in table 2 providing an answer to question 2 of the study. Outcome shows that students imparted using PB method had a higher mean score than those teaching with the $\mathrm{ABL}$ in the learning retention trial. These results stem from the element that PBE promotes hands-on activities that put learning in the students ' fingers. Providing an engaging learning environment in which undergraduates can be involved and actively contribute in lesson discussion enhances the willingness of the undergraduates to address topics and express their personal thoughts. In addition, the teacher's use of open-ended questions lets the students participate in higher order thoughtful activities such as analysis, synthesis, and assessment. Consequently, these boost the academic performance and retention of the students. This affirms the views of Shri-Krishna \& Badri (2013) that the active learning method promotes vigorous information building, improves higher directive thoughtful skills, enhances remembrance and enhances information transference to another condition. He has proved that when the students start to think, they'll be capable of dealing creatively with all kinds of new issues and gain certain trust.

In any enlightening performs, by way of students work or learn to use bitmap image in communities collaboratively, to each one got to think critically about making logical contributions in order to be a successful participant. In addition, as undergraduates learn in classes, the cheerful ones often aid the slow realize the subject matter they are studying. It reinforces Omeje (2013)'s view that collective learning increases serious thoughtful skills and, ultimately, academic performance and learning retaining.

The data obtainable in Table 3 providing an answer to question 4 of the study. Findings revealed that PBE and $\mathrm{ABL}$ are effective in enhancing student interest in technical education, but PB's effect on enhancing student interest in technical education is higher than PBE.

This outcome, especially that PBE is current in stimulating the interest of students in studying Technical Education, tends to support Charif's (2014) writings, which 
wrote that learning in the classroom makes lessons more interesting, allowing students to pay more attention to what is taught and then learned. As also stated by Anandala Kshmi (2012), by means of numerous entry opinions to introduce new material into an activity-based learning classroom would allow teachers to specifically target multiple intellects. This will stimulate the attention of students and engage them in the learning process as well as give them more access to the gratified of the lesson, and additional opportunities to interact with the material. Therefore, the discoveries might be described by the fact that teaching the strengths of the students (intelligences / learning styles) includes the students in the learning progression. As a result, their self-confidence and interest in pursuing Technical Education increased.

Similarly, the finding that the PBE experiential knowledge model is successful in inspiring the attention of students in studying technical education ropes writings by Umar (2012), which claimed that experiential learning is an excellent way to give students control over their progress in learning. This also means the higher the concentration, the greater the inherent incentive for learning. The result could be explained by the fact that this group's experiential knowledge model betrothed students in the learning procedure by having positive effects on the interest of undergraduates in pursuing technical education.

\section{Conclusions}

This research evaluated the impact of place-based and activity-based learning strategies on the accomplishment, attention, and retaining in technical education of students at higher institutions. The place-based learning method used in this study significantly exaggerated Technical Education learning among students. That was reflected in the academic, successes and learning performance of the students. In other words, students learned better technical education and psychomotor skills because they used to be able to actively contribute in teaching and learning in the classroom by communicating with instructor, learning atmosphere and their classmates, working and learning in groups together. Students often maintained the lengthy thinking, while they were permitted to reason about potential resolutions to a problem while interacting with real objects, resources and machines in practical activities. Therefore, it is expected that if the place-based learning method is considered in the training of technical education in higher institutions, skilled craftsmen will graduate from higher institutions with information, Psychomotor competencies, good problem-solving skills, original thoughtful, cooperative work and self-governing policy making skills.

\section{Recommendations}

The following suggestions are made, built on the discoveries of this study;

1. Teachers of technical education will follow the use of the place-based learning approach to technical education teaching.

2. The National Board of Technical Education (NBTE) will deliberate reviewing the curriculum for the Technical Education Program to implement the Place-based Learning Method in Technical Education Teaching.

3. The Ministry of Education and Technical Education administrators should always arrange seminars, and meetings to raise awareness among practical educators about the use of the place-based learning method.

\section{REFERENCES}

[1] Ade. B. (2011). The Challenge - Based Learning on Student's Achievement in Integrated Science and their Perception of their Psycho-Social Environment. A Journal of the Institute of Education, Faculty of Education. Ekiti State University. Educational Focus (EDFOC).3(2).

[2] Anandalakshmy, S. (2012). Activity Based Learning; A Report on an Innovative Method in Tamil Nadu. Retrieved From:

www.ssa.tn.nic.in/docu/abl-report-by-dr.anandhalakshmi.p df.

[3] Anene, G.U. (2009). Home economics and the academic performance of a child. Journals of home economics research, 6,1, 99-103.

[4] Araz (2010) Effects of problem-based learning on the elementary school students' achievement in genetics. Eurasia Journal of Mathematics, Science and Technology Education 4(1) 64-73

[5] Aremu, O.S. \&Adika, L. (2010). The Development and Validation of Academic Performance 5 Factors Inventory: An Unpublished Manuscript, University of Ibadan

[6] Avoseh, O. (2015). The Influence of Sociological and Psychological Factors in Academic Performance of Secondary School Beginners. Journal of Educational Leadership 11:11 - 19

[7] Badri, Y. (2013). Effect of activity-based Approach on Achievement in Science of Students at Elementary Stage International Journal of Basic and Applied Science, Vol 01, No. 04, April 2013, pp. 716-733

[8] Boyle, E.A; Duffy, T \& Dunleavy, K. (2013). Learning styles and academic outcome: The validity and utility of Vermunt's inventory of learning styles in a British higher education setting. British journal of educational psychology.73, 2, 267-290.

[9] Charif (2014) Effects of problem-based learning in Chemistry education on middle school students' academic achievement and attitude. Research in Education on Interdisciplinary. International Research Journal 5(6), $19-30$ 
[10] Damire, O.(2014), planning and evaluation in instruction. Art of teaching pegem publication.

[11] Demmert, G. W. (2011), Improving Academic Performance among native American Students: A Review of the Research Literature. Retrieved March 20, 2006 from http://www.aor.com/pdf

[12] Doolittle, P.E., \& Camp, W. G. (2010). constructivism: the career and technical education perspective. Journal of vocational and technical education, 16(1). retrieved march 25, 2016, from http://scholar.lib.vt.edu/ejournals/JVTE/vl 6n1//doolittle.html.

[13] Federal Republic of Nigeria (2014). National Policy on Education. $4^{\text {th }}$ Edition. Lagos: NERDC Press.

[14] Harbor-Peters, V.F.A. (2012). Although \& Interest of students to the mathematical science in Nigeria. A commissioned paper for the mathematical science education summit 2002 organized by NMC Abuja - 4th -6th October

[15] Haury, D.L., \& Rillero,P. (2014).Perspectives of hands-on science teaching. Columbus, OH: ERIC Clearinghouse for Science, Mathematics, and Environmental Education.

[16] Haynie, W. J. (2010). Effects of take-home tests and study questions on the retention learning in technology education. Journal of technology education $14(2)$. Retrieved on $20^{\text {th }}$ August, 2012 from http//www.scholar/ib.vt.edu/ejournals/JTE/V14n2/haynie.h tml

[17] Kabiru.C. (2010).The effects of Challenge - Based Learning (CBL) on students' cognitive achievement and interest on secondary school French. Unpublished Thesis, University of Ibadan.

[18] Kundu, C.L. and Totoo, D.N. (2017). Educational psychology. New Delhi: sterling publishers private Ltd.

[19] Lumpe, A. T., \& Oliver, J. S. (2011). Dimensions of Hands-on Science. The American Biology Teacher, 53(6), 345-348.

[20] Obodo, G.C (2011). Generating students' interest in mathematics. A paper presented on the NMC/PTDF workshop for secondary school's teachers from 8th -14th February at Awka, Anambra State held at Igwebuike grammar school.

[21] Ogbuanya, T.C. (2008). Workshop organization, safety and Gender Equality in Technical and vocation Education at secondary school level. A paper presented at the workshop organized by south East Zone of National Association of Teachers of Technology held at FCE (T) Umunze on $17^{\text {th }}$ September.

[22] Omeje, H. O. (2013) Effects of Two Models of Problem-Based Learning Approaches on Students Achievement, Interest and Retention in Elementary Structural Design. Unpublished Ph.d thesis, Department of Vocational Teacher Education, University of Nigeria Nsukka.

[23] PEEC (2010). The Benefits of Place-based Education: A Report from the Place-based Education Evaluation Collaborative (Second Edition). Retrieved from http://www.litzsinger.org/PEEC2010_web.pdf.
[24] Resor, C.W. (2010). Place-based education: What is its place in the social studies classroom? The Social Studies, 101(5), 185-188.

[25] Smith, G.A. (2007). Place - based education: breaking through the constraining regularities of public school, Environmental Education Research, 13(2), 189-207.

[26] Smith, G.A. (2012). Place-based education learning to be where we are. Phi Delta Kappan, April, 584-594.

[27] Suydam, Marilyn N., \& Higgins, Jon L. \& ERIC Clearinghouse for Science, Mathematics, and Environmental Education, Columbus, OH. (2012). Activity-based learning in elementary school mathematics: Recommendations from research. Information Reference Center (ERIC/IRC), The Ohio State University.

[28] Umar, H.A. (2012). The Effect of Challenge - Based Learning on Mathematic Self-Efficacy Belief, Interest and Achievement of Low-Achieving Mathematics Students in Kogi State, Nigeria. Journal of Science and Technology.Vol.1, NO.1.

[29] Woodhouse, J. L., ve Knapp, C. E. (2010). Place-based curriculum and instruction: outdoor and environmental education approaches. ERIC Digest. Charleston, WV: ERIC Clearinghouse for Rural Education and Small Schools.(ERIC Document Reproduction Services No. ED 448 012). 